University of Nebraska - Lincoln

DigitalCommons@University of Nebraska - Lincoln

January 1970

\title{
EFFECT OF FEEDING-FASTING INTERVAL ON FINISHING PIGS: WEIGHT GAIN, FEED UTILIZATION AND PHYSICAL AND CHEMICAL CARCASS MEASUREMENTS
}

T. L. Veum

Cornell University

W. G. Pond

New York State College of Agriculture

L. Dale Van Vleck

University of Nebraska-Lincoln, dvan-vleck1@unl.edu

E. F. Walker Jr.

New York State College of Agriculture

L. Krook

New York State Veterinary College

Follow this and additional works at: https://digitalcommons.unl.edu/animalscifacpub

Part of the Animal Sciences Commons

Veum, T. L.; Pond, W. G.; Van Vleck, L. Dale; Walker, E. F. Jr.; and Krook, L., "EFFECT OF FEEDING-FASTING INTERVAL ON FINISHING PIGS: WEIGHT GAIN, FEED UTILIZATION AND PHYSICAL AND CHEMICAL CARCASS MEASUREMENTS" (1970). Faculty Papers and Publications in Animal Science. 328.

https://digitalcommons.unl.edu/animalscifacpub/328

This Article is brought to you for free and open access by the Animal Science Department at DigitalCommons@University of Nebraska - Lincoln. It has been accepted for inclusion in Faculty Papers and Publications in Animal Science by an authorized administrator of DigitalCommons@University of Nebraska - Lincoln. 
Veum, T. L., W. G. Pond, L. D. Van Vleck, E. F. Walker, Jr., and L. Krook. 1970. Effect of feeding-fasting interval on finishing pigs: weight gain, feed utilization and physical and chemical carcass measurements. Journal of Animal Science 30:382-387.

Abstract: Thirty-two Yorkshire pigs (49 kg body weight, 108 days of age) were used to determine the effect of feeding-fasting interval on rate of body weight gain, feed utilization and carcass and organ measurements at a slaughter weight of approximately 90 kilograms. Treatments were: (l) Continuous ad libitum feeding,(2) ad libitum 1 day, fasted on alternate days, (3) ad libitum 1 day, fasted 2 days, (4) ad libitum 1 day, fasted 3 days. Average daily gain was reduced progressively as severity of the fastingfeeding interval was increased. Efficiency of feed utilization, likewise, was reduced as the severity of feed restriction increased, except in group 2(l day ad libitum-1 day fasted) in which efficiency was not significantly different from that in group 1 (continuously ad libitum). Pigs with access to feed only part of the time were able to compensate partially for the time away from feed by consuming more feed during the time of free access to feed. Dressing percent, chilled carcass weight and backfat thickness were progressively reduced and percent lean cuts increased as proportion of fasting time increased. Weight of the empty stomach and intestines progressively increased, as a percentage of carcass weight, as proportion of fasting time increased. Pituitary and thyroid weights, as percentages of carcass weights, were drastically increased by the most severe fasting interval (group 4), although less severe fasting (groups 2 and 3) was not associated with an increase in their weights. Liver fat percentage and liver and kidney weights were not affected by treatment. Adrenal gland weight was increased by the two most severe fasting intervals and this was associated with an increase in thickness of the glomerulosa and fasciculata-reticularis. No other histological changes were noted in any tissue. Myristic and linoleic acid concentrations in both middle and outer layers of backfat decreased as proportion of fasting time increased, while stearic and oleic acid concentrations increased and palmitic remained unchanged.

Copyright $\odot 1970$ American Society of Animal Science. Used by permission. 


\title{
EFFECT OF FEEDING-FASTING INTERVAL ON FINISHING PIGS: WEIGHT GAIN, FEED UTILIZATION AND PHYSICAL AND CHEMICAL CARCASS MEASUREMENTS
}

\author{
T. L. Veum, ${ }^{1}$ W. G. Pond, ${ }^{2}$ L. D. Van Vleck, ${ }^{2}$ E. F. Walker, Jr. ${ }^{2}$ \\ AND L. KROOK ${ }^{3}$ \\ Cornell University, Ithaca, New York ${ }^{4}$
}

$\mathrm{T}$ HE frequency of feeding of laboratory animals has marked effects on metabolism of nutrients (Cohn and Joseph, 1959, 1960a; Cohn et al., 1963; Leveille and Hanson, 1965, 1966; Tepperman and Tepperman, 1958). This is manifested in increased body fat in "meal-fed" rats as compared to "nibblers." It has been suggested (Cohn and Joseph, 1960b; Cohn, 1963) that rate-limiting specific enzymatic reactions may not be capable of handling a single enormous supply of substrate, leading to alternate metabolic pathways and subsequent changes in total body composition. There is less evidence for such an effect in pigs (Braude et al., 1963; Friend and Cunningham, 1964, 1967; Anderson, Fausch and Gesler, 1965). Restriction of daily energy intake to $75 \%$ or less of that consumed under ad libitum conditions has been repeatedly shown to decrease fat and gross energy concentration and increase water, protein and ash in the empty body (Lawes and Gilbert, 1860; Mitchell and Hamilton, 1929; Ellis and Zeller, 1934; Burroughs and Carroll, 1939; Babatunde et al., 1967), carcass (Lawes and Gilbert, 1860; Mitchell and Hamilton, 1929; Cunningham, Friend and Nicholson, 1962; Babatunde et al., 1967) and offal (Lawes and Gilbert, 1860; Mitchell and Hamilton, 1929; Babatunde et al., 1967) of pigs.

The work reported herein was designed to determine the effects of severe feed restriction imposed by regulation of feeding intervals on body weight gain, efficiency of feed utilization and physical and chemical carcass measurements of growing-finishing pigs.

\footnotetext{
1 Present address: Department of Animal Science, University of Missouri, Columbia 65201

${ }^{2}$ Department of Animal Science, New Iork State College of Agriculture.

3 Department of Pathology, New York State Veterinary College.

4 The assistance of Ruth Whetzel, J. A. Dunn, R. Carpenter, G. Kiger, H. Perrine, J. Gallo, I. Reid, R. Banis, I. O'Connor and J. Logomarsino is gratefully acknowledged. Jersey, is ake, American Cyanamid Co., Princeton, New ment.
}

\section{Experimental Procedure}

Thirty-two Yorkshire barrows and gilts averaging $49 \mathrm{~kg}$ and 108 days of age were used in two replicates of 16 each in an experiment with the following treatment variables:

(1) Continuously fed ad libitum from a self-feeder (control group).

(2) Fed ad libitum 1 day (24 hr. starting at $8 \mathrm{am})$ and fasted on alternate days.

(3) Fed ad libitum 1 day and fasted for 2 days.

(4) Fed ad libitum 1 day and fasted for 3 days.

The composition of the diet is shown in table 1. Access to feed was prevented by removing the self-feeder from the pen. Pigs were individually penned in $1 \times 2.7 \mathrm{~m}$ concrete-floor pens. Water was provided $a d$ libitum. Room temperature was thermostatically maintained above $16 \mathrm{C}$.

Blood samples were obtained initially and on 4 consecutive days at 3 -week intervals throughout the experiment for determination of several components. These data are reported elsewhere (Veum et al., 1970). Body weights were recorded during the week of bleeding on the morning following the day all pigs had access to the self-feeders, so as to standardize the influence of gastrointestinal fill.

All pigs were slaughtered between 90 and $94 \mathrm{~kg}$ body weight and were always fed ad libitum the day before slaughter. The gastrointestinal tract was emptied and rinsed with cold water. The liver, kidneys, adrenals, thyroid, pituitary, stomach, small intestine and large intestine were examined grossly for pathological changes, weighed and sampled for histopathology. All tissues saved were fixed in Bouin's solution for 1 to 2 days and stored in $10 \%$ formalin before being sectioned at 6 micra and stained with hematoxylin and eosin. Total liver lipids were determined on a lyophilized $\overline{ }$ sample of homogenized liver (A.O.A.C., 1960). 
TABLE 1. COMPOSITION OF DIET ${ }^{*}$

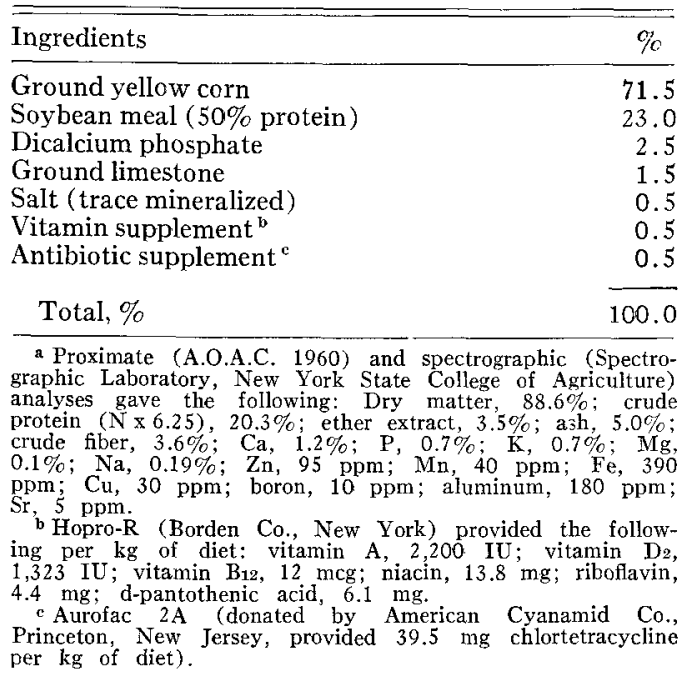

Carcass measurements were taken after 24 hr. chilling at $5 \mathrm{C}$ as follows: Length (anterior edge of first rib to aitch bone), backfat (average of thickness at first rib, last rib and last lumbar vertebra), area of longissimus dorsi (cross-section at 10th rib) and trimmed wholesale cuts. Backfat samples from over the last rib were separated into middle and outer layers (inner layer not included) and the fatty acid composition was determined from methyl esters by gas-liquid chromatography. ${ }^{6}$

The carcass data were analyzed statistically by an unweighted squares of means in a twoway (replicate and treatment) classification with treatment degrees of freedom partitioned into orthogonal comparisons (Steel and Torrie, 1960). Thus is illustrated in table 2. Feed utilization and weight gain data were analyzed by an unweighted squares of means in a two-way classification for each treatment (across periods) with orthogonal polynomials and for each period (across treatments) with orthogonal comparisons. A pariod was designated as the 3 -week interval between blood sampling. Duncan's Multiple Range Test was used to detect differences between means for organ weights, liver fat, adrenal gland zone thickness and fatty acid composition of the backfat for pigs in replicate 2. Total correlation coefficients (Steel and Torrie, 1960) were obtained among variables.

\section{Results and Discussion}

The weight gain and feed utilization data are summarized in table 3 . Average daily gain

\footnotetext{
6 Beckman, Model GC-2A gas chromatograph.
}

TABLE 2. STATISTICAL MODEL FOR ANALYSIS OF VARIANCE OF PERFORMANCE AND CARCASS DATA

\begin{tabular}{lc}
\hline Orthogcnal comparison & $\mathrm{df}$ \\
\hline Replicate (R) 1 vs. R 2 & 1 \\
Treatment (T) 1 vs. T 2 & 1 \\
T 1+T 2 vs. T 3 & 1 \\
T 1+T 2 T 3 vs. 3 T 4 & 1 \\
R T 1 vs. T 2 & 1 \\
R T 1+T 2 vs. 2 T 3 & 1 \\
R T T 1+T 2+T 3 vs.3 T 4 & 1 \\
Error $^{2}$ & 22 \\
\hline
\end{tabular}

a Twenty-two degrees of freedom for all variables; one pig died in each of replicates 1 and 2 . This model does not apply for the data on gland and organ weights, in which only replicate 2 was included.

was depressed progressively with each increase in fasting interval. That is, pigs on treatment 4 , which involved 3 days fasting for every day of ad libitum feeding, suffered the greatest depression in weight gain, while those on treatments 2 and 3, involving 1 and 2 days of fasting, respectively, showed correspondingly less depression. Pigs on treatments 3 and 4 were similar in average daily gain during the first period after which the daily gain of pigs on treatment 3 doubled and remained significantly higher than that of pigs on treatment 4. Efficiency of feed utilization was similar for pigs on treatments 1 and 2, but declined with increasing fasting interval (treatments 3 and 4). This agrees with many reports on limited-fed pigs (Ferrin and McCarty, 1928; Cunningham et al., 1962; Wallace et al., 1965; Babatunde et al., 1966; Passback et al., 1968). Pigs on treatments 3 and 4 were equivalent in efficiency of feed utilization in period 1 , but those on treatment 3 were more efficient subsequently. Pigs fed less frequently partially compensated by consuming more feed during the time it was available. This supports earlier reports (Meade, 1962, Jones and Pond, 1963). Pigs on treatment 2 had access to feed only $50 \%$ of the time but consumed $80 \%$ as much feed

TABLE 3. EFFECT OF FEEDING-FASTING INTERVAL ON WEIGHT GAIN AND GAIN/FEED

\begin{tabular}{|c|c|c|c|c|}
\hline & \multicolumn{4}{|c|}{ Treatment no. } \\
\hline & 1 & 2 & 3 & 4 \\
\hline $\begin{array}{l}\text { No. of pigs } \\
\text { Days on }\end{array}$ & 8 & 8 & 8 & 8 \\
\hline $\begin{array}{l}\text { experiment } \\
\text { Diet consumed on }\end{array}$ & 58 & 73 & $121^{a}$ & $218^{a}$ \\
\hline $\begin{array}{l}\text { libitum, kg } \\
\text { Avg daily gain } \\
\text { Gain/feed }\end{array}$ & $\begin{array}{l}2.83 \\
0.79^{a} \\
0.28\end{array}$ & $\begin{array}{l}4.30 \\
0.63^{a} \\
0.29\end{array}$ & $\begin{array}{l}4.57 \\
0.36 \mathrm{a} \\
0.24^{\mathrm{a}}\end{array}$ & $\begin{array}{l}4.68 \\
0.19^{a} \\
0.16^{\mathrm{a}}\end{array}$ \\
\hline
\end{tabular}


TABLE 4. EFFECT OF FEEDING-FASTING INTERVAL ON CARCASS MEASUREMENTS

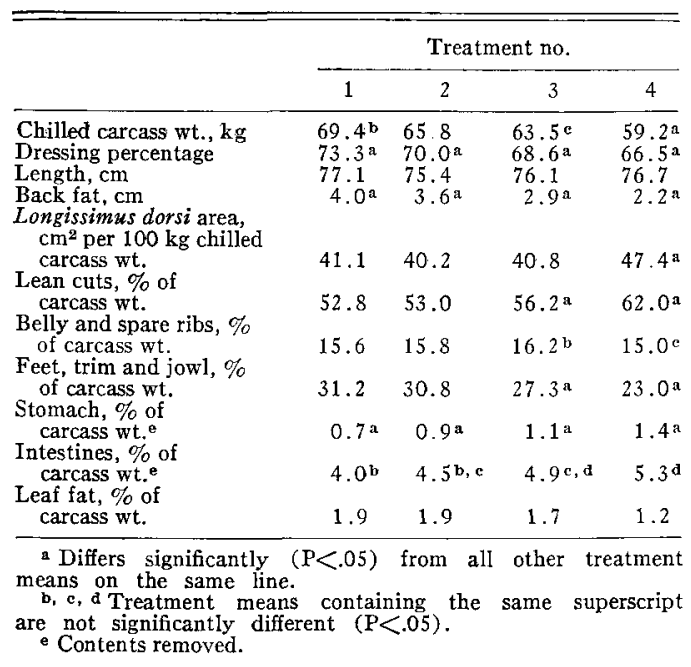

as the controls and required approximately 14 additional days to reach slaughter weight. Pigs on treatments 3 and 4 were able to consume only about 4.6 and $4.7 \mathrm{~kg}$ of feed, respectively, on days they had access to feed as compared to 4.3 for those on treatment 2 and 2.8 for those on treatment 1. Thus, these data indicate that the pigs fed every second, third and fourth day were able to increase their feed intakes to 150,161 and $165 \%$, respectively, of the "normal" level during the time in which they were given access to feed. Baker et al. (1968) came to a similar conclusion after studying the effects of diluting the total diet of finishing swine with graded levels of sand. The weight of the empty stomach and intestinal tract was significantly increased with increased fasting interval (table 4). This increase is in agreement with other reports involving energy restriction by use of diets high in crude fiber (Coey and Robinson, 1954; Bohman, Hunter and McCormick, 1955; Merkel et al., 1958). The hyperphagia shown by intermittently starved rats (Holeckova and Fabry, 1959; Fabry et al., 1962) was associated with a marked hypertrophy of the gastric mucosa and musculature and increased weight of the empty gastrointestinal tract.

Dressing percentage and chilled carcass weight decreased progressively as degree of feed restriction increased (table 4 ). This is in agreement with reports involving feed restriction by limited daily rations (Ellis and Zeller, 1934; Winters, Sierk and Cummings, 1949; Gregory and Dickerson, 1952; Braude et al., 1958, 1963; Breirem, Homb and Husby, 1959; Pickett, Foster and Bache, 1963). There was no significant effect of treatment on carcass length but backfat thickness decreased progressively with increased feed restriction. Cross-sectional area of $l$. dorsi at the 10th rib was not affected by feed restriction except by the most severe fastingfeeding interval (treatment 4 ) which resulted in a significant $(P<.05)$ increase. The decrease in relative fatness associated with feed restriction was also reflected in an increase in percent lean cuts in the carcass among pigs in treatment 4 as compared to those in treatment 3 , and in treatment 3 as compared to treatments 1 and 2. The 1-day feed 1-day fast sequence (treatment 2), while associated with a $20 \%$ reduction in total feed intake and a reduction in rate of weight gain and in backfat thickness, did not produce a significant change in other carcass traits compared to treatment 1 (table 4 ), but carcass leanness was increased by longer fasting (treatments 3 and 4).

Data for organ weights and measurements are summarized in table 5. Liver and kidney weights, as a percentage of chilled carcass weight, were not affected by treatment. This is contrary to the report by McMeekan $(1940 \mathrm{~b})$ in which a high plane of nutrition produced significantly heavier livers and kidneys than a low plane of nutrition, but supports the work of McCance (1960) on undernourished pigs. Weights of the pituitary,

TABLE 5. EFFECT OF FEEDING-FASTING INTERVAL ON ORGAN WEIGHTS, LIVER FAT AND ADRENAL GLAND ZONE THICKNESS

\begin{tabular}{|c|c|c|c|c|}
\hline & \multicolumn{4}{|c|}{ Treatment no. } \\
\hline & 1 & 2 & 3 & 4 \\
\hline & \multicolumn{4}{|c|}{$\%$ of carcass wt. } \\
\hline $\begin{array}{l}\text { Pituitary, X10 } \\
\text { Thyroid, X10 } \\
\text { Adrenals, X10 } \\
\text { Kidneys, X10 } \\
\text { Liver }\end{array}$ & $\begin{array}{l}4.2 \\
8.7 \\
5.4 \\
4.1 \\
2.3\end{array}$ & $\begin{array}{l}4.3 \\
9.9 \\
5.1 \\
4.2 \\
2.5\end{array}$ & $\begin{array}{l}4.9 \\
8.7 \\
6.4^{\mathrm{a}} \\
4.4^{2} \\
2.3\end{array}$ & $\begin{array}{r}6.3^{a} \\
14.6^{a} \\
7.4^{a} \\
4.4 \\
2.3\end{array}$ \\
\hline Liver fat & 11.9 & $\begin{array}{l}\% \text { of li } \\
10.5 \\
\text { Thickne }\end{array}$ & $\begin{array}{l}\text { er wt. } \\
10.0 \\
\text { ss, mm }\end{array}$ & 9.3 \\
\hline $\begin{array}{l}\text { Adrenal glomerulosa, } \\
\mathrm{X} 10^{2} \\
\text { Adrenal fasciculata- } \\
\text { reticularis, X10 }\end{array}$ & $\begin{array}{l}10.7^{b} \\
11.0^{b}\end{array}$ & $\begin{array}{l}10.9^{b} \\
11.8^{b}\end{array}$ & $\begin{array}{l}13.3^{\mathrm{c}} \\
13.8^{\mathrm{c}}\end{array}$ & $\begin{array}{l}14.0^{\mathrm{c}} \\
14.5^{\mathrm{e}}\end{array}$ \\
\hline
\end{tabular}

a Differs significantly $(P<.05)$ from all other treatment means on the same line. nificantly different $(\mathbf{P}<.05)$. 
thyroid and adrenals were significantly $(\mathrm{P}<.05)$ greater among pigs on treatment 4 than among those on other treatments. The adrenal weight of pigs on treatment 3 was also significantly $(\mathbf{P}<.05)$ increased above that of pigs on treatments 1 and 2 , but the extent of the increase was less $(\mathrm{P}<.05)$ than that for pigs on treatment 4.

Histopathology of the pituitary, thyroid, adrenal, kidney, liver, stomach (cardiac, fundic and pyloric regions), small intestine (duodenum, jejunum and ileum) and large intestine revealed no pathological lesions associated with treatment. Measurements of the adrenal cortical zones showed that both the zona fasciculata plus reticularis and the zona glomerulosa were significantly $(\mathrm{P}<.05)$ wider among pigs from treatments 3 and 4 than in those from treatments 1 and 2. This is interpreted as stress associated with the intermittent feeding.

The pigs on treatments 3 and 4 became very physically inactive on the days of fasting and developed lower skin temperatures than those on treatments 1 and 2. McCance and Mount (1960) also reported that severe undernutrition produced significantly lower skin and rectal temperatures in young pigs. Pigs severely restricted (treatments 3 and 4 ) in this study were more irritable and obstinate when restrained for blood sampling. Mild diarrhea was noted occasionally in these pigs a few hours after being given access to feed following 2 or 3 days of fasting, but by the second or third day without feed feces consistency resembled that of sheep feces. Pigs on treatment 2 were active and obstreperous on the days of fasting. McMeekan (1940a) noted that pigs on a low plane of nutrition were extremely active and vociferous compared to pigs fed ad libitum.

The effect of treatment on fatty acid composition of the backfat is summarized in table 6. Only five fatty acids, myristic, palmitic, stearic, oleic and linoleic were measured, and concentrations are expressed as percentages of the total of these five acids. In agreement with others (Hilditch, Lea and Pedelty, 1939; Hilditch and Pedelty, 1940; McMeekan, 1940b; Sink et al., 1964), the outer layer contained a higher percentage of unsaturated acids (oleic and linoleic) and a lower percentage of saturated acids than the middle layer. Increasing the severity of restriction influenced both layers similarly, since there were no significant differences between the two layers when analyzed for each fatty acid across treatments. This is in dis-
TABLE 6. EFFECT OF FEEDING-FASTING INTERVAL ON FATTY ACID COMPOSITION OF BACKFAT

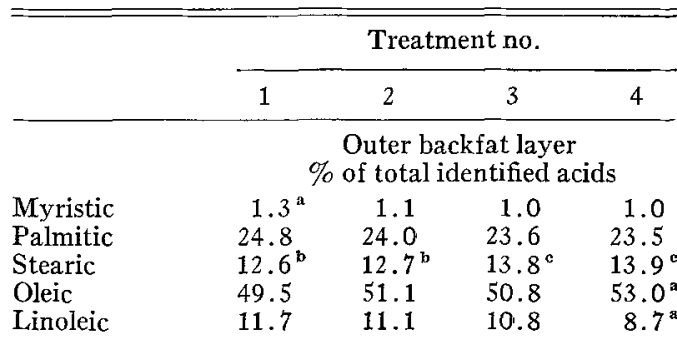

Middle backfat layer ${ }^{\text {‘ }}$ $\%$ of total identified acids

\begin{tabular}{lcccc} 
Myristic & $1.2^{\mathrm{a}}$ & 1.0 & 1.0 & $0.9^{\circ}$ \\
Palmitic & $26.1^{\mathrm{b}}$ & 25.5 & 25.6 & $25.6^{\mathrm{c}}$ \\
Stearic & $15.9^{\mathrm{b}}$ & $15.9^{\mathrm{b}}$ & $17.3^{\mathrm{c}}$ & $17.6^{\mathrm{c}}$ \\
Oleic & $47.2^{\mathrm{b}}$ & $47.6^{\mathrm{c}}$ & $48.4^{\mathrm{c}}$ & $49.3^{\mathrm{c}}$ \\
Linoleic & $9.6^{\mathrm{b}}$ & $9.9^{\mathrm{b}}$ & $7.6^{\mathrm{c}}$ & $6.8^{\mathrm{c}}$ \\
\hline
\end{tabular}

a Differs significantly $(\mathrm{P}<.05)$ from all other treatment means on the same line.

$b$, c Treatment means with different superscripts are significantly different $(\mathrm{P}<.05)$.

d Does not include the third inner layer.

agreement with the statements by McMeekan (1940a, b) and Pomeroy (1941) that the middle layer of backfat is more sensitive to a low plane of nutrition than the outer layer. Backfat of pigs on treatment 1 had a significantly $(P<.05)$ higher percentage of myristic acid in both middle and outer layers than that of pigs on other treatments. There were no differences among treatments in palmitic acid concentration in either layer. Stearic acid concentration of both layers was significantly $(\mathrm{P}<.05)$ lower in backfat of pigs from treatments 1 and 2 than in that of pigs from treatments 3 and 4 . Oleic concentration was higher and linoleic concentration lower in the outer and middle backfat layers of pigs on treatment 4 than in that of pigs on other treatments. The severe feed restriction imposed and the long fasting-feeding interval in treatments 3 and 4 appears to have produced a result different from that reported by most other workers in which feed restriction has been imposed by a limitation in the daily amount rather than by a fasting-feeding sequence. Feed restriction by limitation of the daily amount has been generally reported to result in a higher proportion of unsaturated fatty acids in the backfat as compared to that of ad libitum-fed controls (Ellis and Zeller, 1934; Mansfield, Trehane and Peacock, 1937; McMeekan, 1940a; Sharrock, 1940; Braude et al., 1958; Babatunde et al., 1967). It would appear that the pattern of fatty acid metabolism and deposition in the depot fat is different under conditions of 
continuous restriction of the diet than under conditions of a fasting-ad libitum sequence of restricted feeding. This supports the concept (Cohn et al., 1963) of enzymatic adaptations affecting body composition associated with pattern of feed intake.

\section{Summary}

Thirty-two Yorkshire pigs (49 kg body weight, 108 days of age) were used to determine the effect of feeding-fasting interval on rate of body weight gain, feed utilization and carcass and organ measurements at a slaughter weight of approximately 90 kilograms. Treatments were: (1) Continuous ad libitum feeding, (2) ad libitum 1 day, fasted on alternate days, (3) ad libitum 1 day, fasted 2 days, (4) ad libitum 1 day, fasted 3 days. Average daily gain was reduced progressively as severity of the fasting-feeding interval was increased. Efficiency of feed utilization, likewise, was reduced as the severity of feed restriction increased, except in group 2 ( 1 day ad libitum-1 day fasted) in which efficiency was not significantly different from that in group 1 (continuously ad libitum). Pigs with access to feed only part of the time were able to compensate partially for the time away from feed by consuming more feed during the time of free access to feed.

Dressing percent, chilled carcass weight and backfat thickness were progressively reduced and percent lean cuts increased as proportion of fasting time increased. Weight of the empty stomach and intestines progressively increased, as a percentage of carcass weight, as proportion of fasting time increased. Pituitary and thyroid weights, as percentages of carcass weights, were drastically increased by the most severe fasting interval (group 4), although less severe fasting (groups 2 and 3 ) was not associated with an increase in their weights. Liver fat percentage and liver and kidney weights were not affected by treatment. Adrenal gland weight was increased by the two most severe fasting intervals and this was associated with an increase in thickness of the glomerulosa and fasciculata-reticularis. No other histological changes were noted in any tissue. Myristic and linoleic acid concentrations in both middle and outer layers of backfat decreased as proportion of fasting time increased, while stearic and oleic acid concentrations increased and palmitic remained unchanged.

\section{Literature Cited}

Anderson, T. A., H. D. Fausch and J. Gesler. 1965. The effect of restricted access to feed on growth rate and body composition of swine. Growth 29:213.

A.O.A.C. 1960. Official Methods of Analysis (9th Ed.). Ass. Official Agr. Chemists. Washington, D. C.

Babatunde, G. M., W. G. Pond, L. D. Van Vleck, G. H. Kroening, J. T. Reid, J. R. Stouffer and G. H. Wellington. 1966. Relationships among some physical and chemical parameters of full- vs. limited-fed Yorkshire pigs slaughtered at different live weights. J. Anim. Sci. 25:526.

Babatunde, G. M., W. G. Pond, L. D. Van Vleck, G. H. Kroening and J. T. Reid. 1967. Effect of plane of nutrition, sex and body weight on the chemical composition of Yorkshire pigs. J. Anim. Sci. 26:718.

Baker, D. H., D. E. Becker, A. H. Jensen and B. G. Harmon. 1968. Effect of dietary dilution on performance of finishing swine. J. Anim. Sci. 27:1332.

Bohman, V. R., J. E. Hunter and J. A. McCormick. 1955. The effect of graded levels of alfalfa and aureomycin upon growing-fattening swine. J. Anim. Sci. 14:499.

Braude, R., M. J. Townsend, G. Harrington and J. G. Rowell. 1958. A large-scale test of the effects of food restriction on the performance of fattening pigs. J. Agr. Sci. 51:208.

Braude, R., M. J. Townsend, G. Harrington and J. G. Rowell. 1963. A comparison of feeding pigs once or twice daily. J. Agr. Sci. 60:389.

Breirem, K., T. Homb and M. Husby. 1959. Further trials of feeding methods with bacon pigs. Landbrukshogsk. Inst. Husdyrernoering Foringslaere, Soertrykk No. 176 (Nutr. Abstr. Rev. 29:1405).

Burroughs, Wise and W. E. Carroll. 1939. A new technique for limited feeding experiments. Amer. Soc. Anim. Prod. Proc. p. 407.

Coey, W. E. and K. L. Robinson. 1954. Some effects of dietary crude fiber on liveweight gains and carcass conformation of pigs. J. Agr. Sci. 45:41.

Cohn, C. 1963. Feeding frequency and body composition. Annals N. Y. Acad. Sci. 110:395.

Cohn, C. and D. Joseph. 1959. Changes in body composition attendant as force-feeding. Amer. J. Physiol. 196:965.

Cohn, C. and D. Joseph. 1960a. Effect on metabolism produced by the rate of ingestion of the diet. "Meal Eating" vs. "Nibbling." Amer. J. Clin. Nutr. $8: 682$.

Cohn, C. and D. Joseph. 1960b. Role of rate of ingestion of diet on regulation of intermediary metabolism ("mean eating vs. "nibbling"). Metabolism 9:492.

Cohn, C., D. Joseph, L. Bell and L. Oser. 1963. Feeding frequency and protein metabolism. Amer. J. Physiol. $205: 71$.

Cunningham, H. M., D. W. Friend and J. W. G. Nicholson. 1962. Efficiency of conversion of protein, energy and carbon in pigs restricted late in the fattening period. Can. J. Anim. Sci. 42:176

Ellis, N. R. and J. H. Zeller. 1934. Effect of quantity and kinds of feed on economy of gains and body composition of hogs. U.S.D.A. Tech. Bull. 413.

Fabry, P., R. Petrasek, T. Braun, M. Bednarek, E. Horakova and E. Knopasak. 1962. Lipogenesis in rate adapted to intermittent starvation or continuous underfeeding. Experientia 18:555. 
Ferrin, E. F. and M. A. McCarty. 1928. Shall growing pigs be full-fed? Minn. Agr. Exp. Sta. Bull. 248 .

Friend, D. W. and H. M. Cunningham. 1964. Effects of feeding frequency on metabolism, rate and efficiency of gain and on carcass quality of pigs. J. Nutr. 83:251.

Friend, D. W. and H. M. Cunningham. 1967. Growth, carcass, blood and fat studies with pigs fed once or five times daily. J. Anim. Sci. 26:316.

Gregory, K. E. and G. E. Dickerson. 1952. Influence of heterosis and plane of nutrition on rate and economy of gains, digestion and carcass composition of pigs. Mo. Agr. Exp. Sta. Res. Bull. 493.

Hilditch, T. P., C. H. Lea and H. P. Pedelty. 1939. The influence of low and high planes of nutrition on the composition and synthesis of fat in the pig. Biochem. J. 33:493.

Hilditch, T. P. and W. H. Pedelty. 1940. The influence of prolonged starvation on the composition of pig depot fats. Biochem. J. 34:40.

Holeckova, E. and P. Fabry. 1959. Hyperphagia and gastric hypertrophy in rats adapted to intermittent starvation. Brit. J. Nutr. 13:260.

Jones, J. R. and W. G. Pond. 1963. Relation of feed restriction to carcass quality and performance of growing-finishing swine. Cornell University Swine Mimeo 63-3.

Lawes, J. B. and J. H. Gilbert. 1860. On the composition of oxen, sheep and pigs, and of their increase whilst fattening. J. Royal Agr. Soc. Eng. $21: 433$.

Leveille, G. A. and R. W. Hanson. 1965. Influence of periodicity of eating on adipose tissue metabolism in the rat. Can. J. Physiol. Pharm. 43:857.

Leveille, G. A. and R. W. Hanson. 1966. Adaptive changes in enzyme activity and metabolic path ways in adipose tissue from meal-fed rats. J. Lipid Res. 7:46.

Mansfield, W. S., W. R. Trehane and R. B. Peacock. 1937. Final report of pig feeding experiment conducted on the Cambridge University Farm in 1935 and 1936. J. Royal Agr. Soc. Eng. 98:172.

McCance, R. A. 1960. Severe undernutrition in growing and adult animals. I. Production and general effects. Brit. J. Nutr. 14:59.

McCance, R. A. and L. E. Mount. 1960. Severe undernutrition in growing and adult animals. V. Metabolic rate and body temperature in the pig. Brit. J. Nutr. 14:509.

McMeekan, C. P. 1940a. Growth and development in the pig with special reference to carcass characters. II. The influence of the plane of nutrition on growth and development. J. Agr. Sci. 30:387.

McMeekan, C. P. 1940b. Growth and development in the pig with special reference to carcass char- acters. III. Effect of plane of nutrition on the form and composition of the bacon pig. J. Agr. Sci. $30: 511$.

Meade, R. J. 1962. Protein-energy relationships in rations of growing swine. Proc. Minn. Nutr. Conf., Univ. Minnesota.

Merkel, R. A., R. W. Bray, R. H. Grummer, P. H Phillips and G. Bohstedt. 1958. The influence of limited feeding, using high fiber rations, upon growth and carcass characteristics of swine. II. Effects upon carcass characteristics. J. Anim. Sci. $17: 13$

Mitchell, H. H. and T. S. Hamilton. 1929. Swine type studies. III. The energy and protein requirements of growing swine and the utilization of feed energy in growth. Ill. Agr. Exp. Sta. Bull. 323.

Passback, F. L., Jr., R. W. Rogers, B. G. Diggs and B. Baker, Jr. 1968. Effects of limited feeding on market hogs: performance and quantitative and qualitative carcass characteristics. J. Anim. Sci. $27: 1284$.

Pickett, R. A., J. R. Foster and D. H. Bache. 1963. Feed limitation on performance and carcass characteristics of finishing swine. Purdue Agr. Exp. Sta. Res. Prog. Rep. No. 78.

Pomeroy, R. W. 1941. The effect of a submaintenance diet on the composition of the pig. J. Agr. Sci. $31: 50$.

Sharrock, B. W. 1940. The "restricted" feeding of bacon pigs: a coordinated experiment at centers in Great Britain and Ireland. J. Agr. Sci. 30:598.

Sink, J. D., J. L. Watkins, J. H. Ziegler and R. C. Miller. 1964. Analyses of fat deposition in swine by gas-liquid chromatography. J. Anim. Sci. $23: 121$

Steel, R. G. D. and J. H. Torrie. 1960. Principles and Procedures of Statistics. McGraw-Hill Book Co., Inc., New York.

Tepperman, H. M. and J. Tepperman. 1958. Effects of anticedent food intake pattern on hepatic lipogenesis. Amer. J. Physiol. 193:55

Veum, T. L., W. G. Pond, L. D. VanVleck and E. F. Walker. 1970. Effect of feeding-fasting interval on finishing pigs: blood urea and serum lipids, cholesterol and protein concentrations. J. Anim. Sci. 30:388.

Wallace, H. D., A. Z. Palmer, J. W. Carpenter and G. E. Combs. 1965. A study of the relationship of feed restriction and dietary protein level in

finishing hogs. Florida Agr. Exp. Sta. Rep. Mimeo Series AN 65-9.

Winters, L. M., C. F. Sierk and J. N. Cummings. 1949. The effects of plane of nutrition on the economy of production and carcass quality of swine. J. Anim. Sci. 8:132. 